\title{
PEMBERIAN PUPUK KASCING DAN POC NASA PADA PERTUMBUHAN DAN PRODUKSI BAWANG MERAH (Allium ascalonicum L.)
}

\author{
Provision of Kascing Fertilizer and POC Nasa in Growth and Production of \\ Shallot (Allium ascalonicum L.)
}

Eni Farida, Saripah Ulpah, T. Edy Sabli

Program Studi Agroteknologi, Fakultas Pertanian Universitas Islam Riau

Jl. Khaharuddin Nasution No.113 Pekanbaru. 28284

[Diterima: November 2018; Disetujui: Desember 2018]

\begin{abstract}
The purpose of this study was to determine the effect of applying vermicompost fertilizer and POC Nasa on the growth and production of shallots (Allium ascalonicum L.). This research has been carried out in the Experimental Garden of the Faculty of Agriculture, Riau Islamic University for 4 months, starting from July to October 2018. The design used in this study was a factorial Completely Randomized Design consisting of 2 factors. The first factor is vermicompost fertilizer (K) which consists of 4 levels namely 0, 200, 400, $600 \mathrm{~g} /$ plot and the second factor is POC Nasa (P) consisting of 4 levels namely $0,2,4,6 \mathrm{cc} / 1$ water. The parameters observed in this study were plant height, harvest age, number of tubers per clump, wet tuber weight per sample, dry tuber weight per sample, tuber weight loss. The last observation data were statistically analyzed and continued with a BNJ follow-up test at the 5\% level. The results showed that the application of vermicompost fertilizer and poc nasa interaction significantly affected the parameters of plant height, age of harvest, the number of tubers per clump, dry tuber weight per sample, shrinkage of tuber weight, and the application of vermicompost fertilizer and poc nasa interactively had no significant effect on wet tuber weight parameters per sample with the best treatment is a concentration of $600 \mathrm{~g} / \mathrm{plot}(\mathrm{K} 3)$ and $6 \mathrm{cc} /$ water (P3) is a dose of 44.80 grams/plot.
\end{abstract}

Keywords: POC, Kascing, Shallot

\begin{abstract}
ABSTRAK
Tujuan penelitian ini adalah untuk mengetahui pengaruh pemberian pupuk kascing dan POC Nasa pada pertumbuhan dan produksi bawang merah (Allium ascalonicum L.). Penelitian ini telah dilaksanakan di Kebun Percobaan Fakultas Pertanian Universitas Islam Riau selama 4 bulan, terhitung dari bulan Juli sampai Oktober 2018. Rancangan yang digunakan dalam penelitian ini adalah Rancangan Acak Lengkap faktorial yang terdiri dari 2 faktor. Faktor pertama adalah pupuk kascing (K) yang terdiri dari 4 taraf yaitu 0, 200, 400, $600 \mathrm{~g} / \mathrm{plot}$ dan faktor kedua adalah POC Nasa (P) yang terdiri dari 4 taraf yaitu $0,2,4,6 \mathrm{cc} / \mathrm{l}$ air. Parameter yang diamati pada penelitian ini adalah tinggi tanaman, umur panen, jumlah umbi per rumpun, berat umbi basah per sampel, berat umbi kering per sampel, susut bobot umbi. Data pengamatan terakhir dianalisis secara statistik dan dilanjutkan dengan uji lanjut BNJ pada taraf $5 \%$. Hasil penelitian menunjukkan bahwa pemberian pupuk kascing dan poc nasa secara interaksi berpengaruh nyata terhadap parameter tinggi tanaman, umur panen, jumlah umbi per rumpun, berat umbi kering per sampel, susut bobot umbi, dan pemberian pupuk kascing dan poc nasa secara interaksi berpengaruh tidak nyata terhadap parameter berat umbi basah per sampel dengan perlakuan terbaik adalah konsentrasi $600 \mathrm{~g} / \mathrm{plot}(\mathrm{K} 3)$ dan $6 \mathrm{cc} / \mathrm{l}$ air (P3) adalah dosis 44,80 gram/plot.
\end{abstract}

Kata Kunci: POC Nasa, Kascing, Bawang Merah 


\section{PENDAHULUAN}

Bawang merah merupakan komoditi pertanian yang merupakan kebutuhan harian, umumnya bagi masyarakat indonesia. Bawang merah termasuk tanaman rempah yang berperan sebagai bumbu penyedap masakan dan digunakan juga sebagai bahan obat tradisional.

Penggunaan bawang merah selain sebagai bumbu masak setelah cabe, bawang merah juga dapat dijual ataupun diolah dalam bentuk olahan seperti ekstrak bawang merah, bumbu, minyak atsiri, bawang goring, bahkan sebagai obat untuk menurunkan kadar kolestrol, gula darah, mencegah penggumpalan darah, menurunkan tekanan darah serta memperlancar aliran darah.(Suriani, 2012)

Tanaman bawang merah juga sudah sejak lama telah diusahakan oleh petani secara intensif, karena bawang merah memiliki nilai ekonomis yang tinggi dan dapat ditinjau dari sisi pemenuhan konsumsi nasional, sumber penghasilan petani maupun potensinya sebagai penghasil devisa negara.

Di Sumatera, terdapat beberapa daerah yang menjadi sentra produksi bawang merah yakni Sumatera Barat dan Sumatera Utara. Pemenuhan bawang merah di Provinsi Riau masih tergantung dari daerah Provinsi Sumatera Barat, Jawa maupun dari Sumatera Utara (Sianipar., 2015).

Produksi bawang merah di Provinsi Riau pada tahun 2013 yaitu 12 ton dengan luas $3 \mathrm{Ha}$. Sedangkan tahun 2014 dengan luas lahan 14 ha menghasilkan produksi sebanyak 89 ton sedangkan pada tahun 2015 produksi bawang merah di Riau mengalami kenaikan dengan total produksi 140 ton/ha (Badan Pusat Statistik, 2016). Meskipun terjadi peningkatan produksi, untuk memenuhi kebutuhan bawang merah baik untuk konsumsi maupun industri khususnya di Provinsi Riau masih belum mencukupi dan tergolong sangat rendah. Permintaan bawang merah untuk daerah pekanbaru mencapai 1.746 ton (Anonimous, 2015).

Salah satu faktor yang mempengaruhi produksi bawang merah di Provinsi Riau adalah kondisi tanah yang kurang baik serta miskin unsur hara akibat digunakan secara terus menerus oleh petani. Diperlukan upaya penerapan teknologi yang sesuai untuk meningkatkan hasil produksi bawang merah, teknologi yang dapat diterapkan dalam budidaya bawang merah akibat tanah yang kekurangan unsur hara adalah melalui pemupukan.

Pertumbuhan dan perkembangan tanaman bawang merah sangat dipengaruhi oleh pemberian pupuk dan ketersediaan unsur hara di dalam tanah. Serapan unsur hara dibatasi oleh unsur hara yang berada dalam keadaan minimum. Dengan demikian status hara terendah akan mengendalikan proses pertumbuhan tanaman. Untuk mencapai pertumbuhan optimal, seluruh unsur hamra harus dalam keadaan seimbang (Pahan, 2008).

Pupuk organik merupakan bahan pembenah tanah yang paling baik dan alami dari pada bahan pembenah buatan.Pada umumnya pupuk organik mengandung unsur hara makro N, P, K rendah, tetapi mengandung hara mikro dalam jumlah cukup yang sangat diperlukan pertumbuhan tanaman.Sebagai bahan pembenah tanah, pupuk organik mencegah terjadinya erosi, pergerakan permukaan tanah dan retakan tanah, dan mempertahankan kelengasan tanah (Sutanto, 2005).

Salah satu pupuk organik yang mengandung unsur hara yang lengkap, baik unsur mikro maupun makro yang berguna bagi pertumbuhan tanaman adalah kascing.Kascing ini mengandung partikel-partikel kecil dari bahan organik yang dimakan cacing dan kemudian dikeluarkan lagi.Kandungan kascing tergantung pada bahan organik dan jenis cacingnya.Namun, umumnya kascing mengandung unsur hara yang dibutuhkan tanaman seperti nitrogen, fosfor, mineral dan vitamin (Mulat, 2003).

Kascing merupakan tanah bekas pemeliharaan cacing merupakan produk samping dari budidaya cacing tanah yang berupa pupuk organik sangat cocok untuk pertumbuhan tanaman karena dapat meningkatkan kesuburan tanah. Kascing mengandung berbagai bahan yang dibutuhkan untuk pertumbuhan tanaman yaitu suatu hormon seperti giberelin, sitokinin, dan auxin serta mengandung unsur hara $(\mathrm{N}, \mathrm{P}, \mathrm{K}, \mathrm{Mg}$. dan Ca) serta Azobacter $s p$ yang merupakan bakteri penambah $\mathrm{N}$ non-simbiotik yang membantu memperkaya unsur $\mathrm{N}$ yang diperlukan oleh tanaman. 
Guna memenuhi kebutuhan bawang merah yang terus meningkat maka perlu adanya terobosan teknologi budidaya yang mampu meningkatkan produksi bawang merah yaitu melalui pendekatan teknologi organik.Pertanian organik mampu meningkatkan produktifitas bawang merah. Selain itu di dalam masyarakat saat ini sudah mulai menerapkan pola hidup sehat dengan mengkonsumsi produk organik, serta pertanian organik juga mampu untuk mengurangi atau meminimalkan penggunaan pupuk kimia sintetik.Oleh karena itu, salah satu alternatif untuk meningkatkan produktifitas bawang merah yaitu dengan menggunakan pupuk organik cair.Pupuk organik cair adalah larutan dari pembusukan bahan-bahan organik yang berasal dari sisa tanaman, kotoran hewan, dan manusia yang kandungan unsur haranya lebih dari satu unsur.Kelebihan dari pupuk organik ini adalah dapat secara cepat mengatasi defesiensi hara, tidak masa-lah dalam pencucian hara, dan mampu menyediakan hara secara cepat (Samad, 2008).

Seiring dengan perkembangan teknologi pertanian, telah dikembangkan pupuk organik alami yang dapat digunakan untuk membantu mengatasi kendala produksi pertanian. Pupuk organik cair NASA atau lebih di kenal dengan NASA merupakan pupuk organik cair alami $100 \%$ dari ekstraksi bahan organik limbah ternak dan unggas, limbah tanaman, limbah alam, beberapa jenis tanaman tertentu dan "bumbu-bumbu atau zat-zat alami" lainnya yang diproses berdasarkan teknologi berwawasan lingkungan dengan prinsip Zero Emision Concept (Damari, 2012).Berdasarkan uraian diatas, penulis telah melakukan penelitian dengan judul "Pemberian Pupuk Kascing Dan Pupuk Organik Cair Nasa Terhadap Pertumbuhan Dan Produksi Bawang Merah (Allium ascalonicum L.)".

\section{BAHAN DAN METODE}

\author{
Penelitian ini telah dilaksanakan di \\ Kebun Percobaan Fakultas Pertanian \\ Universitas Islam Riau, Jalan Kaharuddin \\ Nasution Km 11 No. 113.Kelurahan Air \\ Dingin, Kecamatan Bukit Raya Kota \\ Pekanbaru. Penelitian ini dilakukan selama
}

empat bulan, terhitung dari bulan Juli sampai Oktober 2018.

Bahan yang digunakan dalam penelitian ini adalah umbi bawang merah Varietas Brebes, pupuk kascing, pupuk organik cair NASA, Dithane M-45, Decis 25 EC, polybag ukuran $35 \times 40 \mathrm{~cm}$, tali raffia, dan plat seng.

Alat- alat yang digunakan adalah cangkul, pisau,ember, hand spayer, timbangan analitik, gembor, kamera, meteran, dan alat-alat tulis.

Penelitian ini merupakan percobaan faktorial 4x4 dalam Rancangan Acak Lengkap yang terdiri dari 2 faktor. Faktor yang pertama adalah dosis Pupuk Kascing (K) terdiri dari 4 taraf dan faktor kedua adalah konsentrasi Pupuk Organik Cair Nasa (P) terdiri dari 4 taraf sehingga diperoleh 16 kombinasi perlakuan. Setiap kombinasi perlakuan terdiri dari 3 kali ulangan, sehingga terdapat 48 satuan percobaan. Setiap plot terdiri dari 4 tanaman dan 2 tanaman dijadikan sebagai sampel yang diambil secara acak, penelitian ini terdiri dari 192 tanaman.

Data hasil pengamatan dari masing-masing perlakuan dianalisis secara statistik, apabila $\mathrm{F}$ hitung lebih besar dari $\mathrm{F}$ tabel maka dilanjutkan dengan uji lanjut BNJ (Beda Nyata Jujur) pada taraf $5 \%$.

\section{HASIL DAN PEMBAHASAN}

\section{Tinggi Tanaman (cm).}

Hasil pengamatan tinggi tanaman bawang merah setelah dilakukan analisis ragam menunjukan bahwa secara interaksi maupun pengaruh utama pemberian pupuk kascing dan POC NASA nyata terhadap tinggi tanaman. Rerata hasil pengamatan tinggi tanaman setelah dilakukan uji lanjut BNJ pada taraf 5\% dapat dilihat pada Tabel 1.

Data pada Tabel 1,menunjukkan bahwa secara interaksi perlakuan pupuk kascing dan POC NASAnyata terhadap tinggi tanaman bawang merah. Kombinasi perlakuan pupuk kascing $600 \mathrm{~kg} / \mathrm{plot}$ dan POC NASA $6 \mathrm{cc} / \mathrm{l}$ air (K3P3) merupakan perlakuan terbaik dengan tinggi tanaman yaitu $46,57 \mathrm{~cm}$, tidak berbeda nyata dengan perlakuan K2P3, K3P2 dan berbeda nyata dengan perlakuan lainnya. 
Tabel 1. Rata-rata tinggi tanaman bawang merah dengan perlakuan pupuk Kascing dan poc nasa $(\mathrm{cm})$.

\begin{tabular}{clllll}
\hline \multirow{2}{*}{$\begin{array}{c}\text { Kascing } \\
\text { g/tanaman })\end{array}$} & \multicolumn{4}{c}{ POC NASA (cc/l air) } & \multirow{2}{*}{ Rerata } \\
\cline { 2 - 4 } K0 (0) & $28,50 \mathrm{~d}$ & $29,83 \mathrm{~cd}$ & $34,80 \mathrm{bc}$ & $36,20 \mathrm{~b}$ & $32,33 \mathrm{c}$ \\
K1 (200) & $29,33 \mathrm{~cd}$ & $34,23 \mathrm{bc}$ & $35,40 \mathrm{~b}$ & $36,47 \mathrm{~b}$ & $33,86 \mathrm{c}$ \\
K2 (400) & $33,67 \mathrm{bcd}$ & $33,00 \mathrm{bcd}$ & $38,07 \mathrm{~b}$ & $43,97 \mathrm{a}$ & $37,18 \mathrm{~b}$ \\
K3 (600) & $36,57 \mathrm{~b}$ & $37,93 \mathrm{~b}$ & $44,03 \mathrm{a}$ & $46,57 \mathrm{a}$ & $41,28 \mathrm{a}$ \\
\hline \multicolumn{1}{c}{ Rerata } & $32,02 \mathrm{c}$ & $33,75 \mathrm{c}$ & $38,08 \mathrm{~b}$ & $40,80 \mathrm{a}$ & \\
\hline KK=5,02 & BNJK\&P=2,01 & & BNJ KP $=5,53$ & \\
\hline
\end{tabular}

Angka-angka pada baris dan kolom yang diikuti oleh huruf kecil yang sama tidak berbeda nyata menurut uji lanjut BNJ pada taraf $5 \%$

Tingginya tanaman bawang merah dikarenakan ada pengaruh dosis pemberian pupuk kascing dan poc nasa yang sudah mampu memenuhi kebutuhan unsur hara makro dan mikro karena kascing mengandung bahan atau komponen yang bersifat biologis maupun kimiawi yang sangat dibutuhkan oleh tanaman dan mengandung hormon pengatur tumbuh seperti giberelin, sitokinin, dan auksin serta unsur yang berperan dalam pertumbuhan $\mathrm{N}, \mathrm{P}$, $\mathrm{K}, \mathrm{Mg}$ dan $\mathrm{Ca}$. Sehingga pertumbuhan vegetatif berlangsung optimal karena jumlah energy yang dihasilkan dapat mendorong pemanjangan meristem ujung tanaman untuk mengoptimalkan tinggi tanaman bawang merah.
Pupuk organik cair nasa merangsang pembentukan polifenol yaitu salah satu senyawa yang diperlukan tanaman untuk daya tahan tumbuhan terhadap sengan penyakit.

\section{Umur Panen (hari)}

Hasil pengamatan umur panen bawang merah setelah dilakukan analisis ragam menunjukkan bahwa baik secara interaksi maupun pengaruh utama pemberian pupuk kacing dan pocnasa nyata terhadap umur panen. Rerata umur panen setelah dilakukan uji BNJ pada taraf $5 \%$ terlihat pada tabel 2 .

Tabel 2. Rata-rata umur panen bawang merah dengan perlakuan pupuk Kascing dan poc nasa (hari)

\begin{tabular}{|c|c|c|c|c|c|}
\hline \multirow{2}{*}{$\begin{array}{c}\text { Pupuk Kascing } \\
\text { (g/plot) }\end{array}$} & \multicolumn{4}{|c|}{ POC NASA (cc/l air) } & \multirow{2}{*}{ Rerata } \\
\hline & $\mathrm{P} 0(0)$ & $\mathrm{P} 1(2)$ & $\mathrm{P} 2(4)$ & P3 (6) & \\
\hline K0 (0) & $59,67 \mathrm{~g}$ & $58,33 \mathrm{fg}$ & $56,67 \mathrm{def}$ & $56,00 \mathrm{cde}$ & $57,67 \mathrm{~b}$ \\
\hline K1 (200) & 57,33 ef & 56,33 cde & $56,67 \mathrm{def}$ & $55,33 \mathrm{bcd}$ & $56,42 \mathrm{~b}$ \\
\hline K2 (400) & 56,33 cde & 56,33 cde & $54,67 a b c$ & $55,00 \mathrm{bcd}$ & $55,58 \mathrm{~b}$ \\
\hline K3 (600) & 56,00 cde & 55,67 bcde & $54,00 \mathrm{ab}$ & $53,00 \mathrm{a}$ & $54,67 \mathrm{a}$ \\
\hline Rerata & $57,33 \mathrm{~b}$ & $56,67 \mathrm{~b}$ & $55,5 \mathrm{ab}$ & $54,83 \mathrm{a}$ & \\
\hline $\mathrm{KK}=1,05 \%$ & BNJK\&P $=0,66$ & & & $\mathrm{BNJ} \mathrm{KP}=1,8$ & \\
\hline
\end{tabular}

Angka-angka pada baris dan kolom yang diikuti oleh huruf kecil yang sama tidak berbeda nyata menurut uji lanjut BNJ pada taraf $5 \%$

Data pada Tabel 2, menunjukkan bahwa secara interaksi maupun pengaruh utama pemberian pupuk kascing dan poc nasa nyata terhadap umur panen bawang merah dengan kombinasi pupuk kascing dan poc nasa sebanyak $600 \mathrm{~g} / \mathrm{plot}$ dan $6 \mathrm{cc} / \mathrm{l}$ air (K3P3) merupakan perlakuan terbaik dengan umur panen tercepat yaitu 53,00 HST, tidak berbeda nyata dengan perlakuan K3P2 sedangkan umur panen terlama yaitu tanpa pemberian pupuk kascing dan tanpa pemberian poc nasa (K0P0) dengan umur panen yaitu 57,67 hst.
Cepatnya umur panen pada perlakuan K3P3 dibandingkan dengan perlakuan lainnya hal ini disebabkan pemberian pupuk kascing dengan dosis $600 \mathrm{~g} /$ plotdan poc nasa dengan dosis $6 \mathrm{cc} / \mathrm{l}$ air telah memenuhi kebutuhan unsur hara tanaman, sehingga mampu meningkatkan metabolisme dalam jaringan tanaman yang akibatnya tanaman lebih memacu pertumbuhan vegetatif untuk memasuki pertumbuhan generatif khususnya dalam mempercepat masa panen.

Terjadinya perbedaan dari masingmasing interaksi perlakuan bahwa pemberian pupuk kascing dan poc nasa (K3P3) ada 
pengaruh secara interaksi terhadap percepatan masa umur panen ini dapat dilihat bahwa secara interaksi K3P3 lebih cepat dibandingkan dengan perlakuan lainnya, karena pupuk kascing terdapat unsur $\mathrm{P}$ yang sangat berperan dalam pembentukan umbi. Pupuk kascing memiliki kandungan unsur hara makro dan mikro serta hormone zat pengatur tumbuh yang berperan penting bagi tanaman dalam meningkatkan pertumbuhan dan produksinya, dimana dengan dosis $600 \mathrm{~g} / \mathrm{plot}$ dan $6 \mathrm{cc} / \mathrm{l}$ air (K3P3) telah mampu memenuhi kebutuhan hara tanaman sehingga umur panen dari tanaman menjadi lebih cepat.

Dapat penulis simpulkan yang berdasarkan pendapat diatas bahwa tanaman didalam metabolisme ditentukan beberapa unsur yaitu seperti unsur nitrogen fosfor, kuliun pada tanaman yang yang dalam jumlah cukup, sehingga hal ersebut mempengaruhi umur panen atau dalam fase vegetatif dan generatif tanaman.

\section{Jumlah Umbi Per Rumpun (umbi)}

Hasil pengamatan jumlah umbi per rumpun bawang merah setelah dilakukan analisis ragam menunjukkan bahwa secara interaksi maupun pengaruh utama pemberian kascing dan poc nasa nyata terhadap jumlah umbi perumpun. Rerata hasil pengamatan terhadap jumlah umbi setelah dilakukan uji BNJ pada taraf 5\% dapat dilihat pada tabel 3.

Tabel 3. Rerata jumlah umbi per rumpun bawang merah dengan perlakuan pupuk kascing dan poc nasa(umbi)

\begin{tabular}{|c|c|c|c|c|c|}
\hline \multirow{2}{*}{$\begin{array}{l}\text { Pupuk Kascing } \\
\text { (g/plot) }\end{array}$} & \multicolumn{4}{|c|}{ Poc nasa (cc/l air) } & \multirow{2}{*}{ Rerata } \\
\hline & $\begin{array}{l}\mathrm{P} 0(0) \\
\end{array}$ & $\begin{array}{l}\text { P1 (2) } \\
\end{array}$ & P2 (4) & P3 (6) & \\
\hline K0 (0) & $4,00 \mathrm{j}$ & 5,33 hij & $6,33 \mathrm{ghi}$ & 7,33 efg & $5,75 \mathrm{~d}$ \\
\hline K1 (200) & $4,67 \mathrm{ij}$ & $6,67 \mathrm{fgh}$ & $8,33 \mathrm{ef}$ & $8,67 \mathrm{de}$ & $7,08 \mathrm{c}$ \\
\hline K2 (400) & 5,67 ghij & 7,33 efg & $10,67 \mathrm{bc}$ & $12,33 \mathrm{ab}$ & $9,00 \mathrm{~b}$ \\
\hline K3 (600) & 7,33 efg & $10,33 \mathrm{~cd}$ & $12,00 \mathrm{abc}$ & $13,33 \mathrm{a}$ & $10,75 \mathrm{a}$ \\
\hline Rerata & $5,42 \mathrm{~d}$ & $7,42 \mathrm{c}$ & $9,33 \mathrm{~b}$ & $10,42 \mathrm{a}$ & \\
\hline $\mathrm{KK}=7,26 \%$ & $\mathrm{BNJK}=0,66$ & $\mathrm{BNJ} P=\mathrm{C}$ & & $\mathrm{BNJ} \mathrm{KP}=1,8$ & \\
\hline
\end{tabular}

Angka-angka pada baris dan kolom yang diikuti oleh huruf kecil yang sama tidak berbeda nyata menurut uji lanjut BNJ pada taraf $5 \%$

Data pada Tabel 3.menunjukan bahwa secara interaksi perlakuan pupuk kascing dan POC NASA nyata terhadap jumlah umbi per rumpun bawang merah. Perlakuan yang menghasilkan jumlah umbi terbanyak adalah K3 (600 g/plot) yaitu 13,33 umbi tidak berbeda nyata pada K2 (400 g/plot) yaitu 9 dan berbeda nyata terhadap perlakuan $\mathrm{K} 1$ dan $\mathrm{K} 0$ dengan masing-masing jumlah umbi 7,08 dan 5,75 umbi, dimana perlakuan yang menghasilkan jumlah umbi yang paling sedikit adalah K0 (tanpa pemberian pupuk kascing) yaitu 5,75 umbi.

Banyaknya jumlah umbi yang dihasilkan melalui pemberian pupuk kascing yang mana jumlah umbi yang terbanyak dihasilkan pada pemberian pupuk kascing $600 \mathrm{~g} /$ plot (K3) dan tidak berbeda nyata pada K2 hal ini dikarenakan pada dosis tersebut pupuk kascing yang diberikan dapat mendukung pertumbuhan bawang merah kearah yang lebih baik, karena pupuk kascing dapat memperbaiki sifat fisik tanah, kimia dan biologi tanah seperti menyuburkan tanah, menambah unsur hara dan dapat meningkatkan kapasitas air, dimana pupuk kascing mengandung unsur hara makro dan mikro $\mathrm{C}, \mathrm{N}, \mathrm{P}, \mathrm{K}, \mathrm{Ca}, \mathrm{Mg}, \mathrm{Zn}, \mathrm{Fe}, \mathrm{Mn}$, Fulfat dan mengandung hormone pengatur tumbuh seperti giberelin, sitokinin, dan auksin. Hal ini sesuai dengan pernyataan Fahrudin (2009) yang menyatakan bahwa pupuk kascing mengandung unsur hara yang dibutuhkan tanaman serta pemberian kompos kascing juga dapat memperbaiki struktur tanah, menetralkan $\mathrm{pH}$ tanah, serta mampu menahan air dan dapat mendukung pertumbuhan tanaman menjadi baik.

Menurut Suryana (2008), suatu tanaman akan tumbuh dan berkembang dengan subur apabila unsur hara yang diberikan dapat diserap oleh suatu tanaman dan dalam bentuk yang sesuai untuk diserap akar serta dalam keadaan yang cukup.

Nugrahini (2013) menyatakan bahwa respon tinggi tanaman pada umur 20, 40 dan 60 hari 
setelah tanam, jumlah daun pada umur 20, 40 dan 60 hari setelah tanam, jumlah anakan pada umur 40 dan 60 hari setelah tanam, berat umbi per petak, dan produksi umbi berbeda sangat nyata terhadap konsentrasi POC Nasa. Produksi umbi paling tinggi dihasilkan pada perlakuan POC Nasa dengan konsentrasi 3 ml 1-1 air (p4) yaitu 9,12 Mg ha-1.

\section{Berat Umbi Basah Per rumpun(gram)}

Hasil pengamatan berat umbi basah bawang merah setelah dilakukan analisis ragam menunjukkan bahwa interaksi pupuk kascing dan poc nasa tidak memberikan pengaruh nyata terhadap berat umbi basah per tanaman bawang merah, tetapi pengaruh utama kascing dan poc nasa nyata terhadap berat umbi basah per tanaman bawang merah. Rerata hasil pengamatan terhadap berat umbi basah setelah dilakukan uji BNJ pada taraf 5\% dapat dilihat pada tabel 4 .

Tabel 4. Rerata berat umbi basah pertanaman bawang merah dengan perlakuan pupuk kascing dan poc nasa (gram).

\begin{tabular}{|c|c|c|c|c|c|}
\hline \multirow{2}{*}{$\begin{array}{l}\text { Pupuk kascing } \\
\text { (g/plot) }\end{array}$} & \multicolumn{4}{|c|}{ Poc nasa(cc/l air) } & \multirow{2}{*}{ Rerata } \\
\hline & P0 (0) & P1 (2) & P2 (4) & P3 (6) & \\
\hline K0 (0) & 25,00 & 28,33 & 32,37 & 36,50 & $30,55 \mathrm{~d}$ \\
\hline K1 (200) & 27,67 & 32,37 & 38,83 & 41,13 & $35,00 \mathrm{c}$ \\
\hline K2 (400) & 33,77 & 38,87 & 45,10 & 48,60 & $41,59 b$ \\
\hline K3 (600) & 37,77 & 43,10 & 48,00 & 50,33 & $44,80 \mathrm{a}$ \\
\hline Rerata & $31,05 \mathrm{~d}$ & $35,66 \mathrm{c}$ & $41,08 \mathrm{~b}$ & $44,15 \mathrm{a}$ & \\
\hline $\mathrm{KK}=4,73 \%$ & & $\mathrm{BNJ} \mathrm{K}=1,48$ & & $\mathrm{BNJP}=1,21$ & \\
\hline
\end{tabular}

Angka-angka pada baris dan kolom yang diikuti oleh huruf kecil yang sama tidak berbeda nyata menurut uji lanjut BNJ pada taraf $5 \%$

Data pada tabel 4 dapat dilihat bahwa hasil terbaik terdapat pada perlakuan K3 (600 $\mathrm{g} / \mathrm{plot}$ ) yaitu 44,80g/plot secara utama kombinasi pemberian pupuk kascing dan poc nasa memberikan pengaruh nyata terhadap berat umbi basah per tanaman umbi basah tanaman bawang merah, dimana perlakuan terbaik yaitu $(600 \mathrm{~g} / \mathrm{plot})$ yaitu $44,80 \mathrm{~g}$. Sedangkan perlakuan yang menghasilkan berat basah terendah yaitu tanpa pupuk kascing (K0) yaitu $30,55 \mathrm{~g}$.

Tinggi angka pada K3 dengan dosis 600 $\mathrm{g} /$ plot sudah memenuhi kebutuhan hara tanaman bawang merah, hal ini sehingga tanaman mampu melaksanakan proses metabolisme dengan baik serta kondisi tanah menjadi subur sehingga tanaman dapat tumbuh dengan baik, kemudian diimbanginya dengan pemberian unsur.

Pupuk organik adalah pupuk yang tersusun dari materi makhluk hidup, seperti pelapukan sisa-sisa tanaman, hewan yaitu kotorannya hewan hewan seperti: kotoran hewan: sapi, kambing, ayam, dan lain sebagainya. Pupuk organik dapat terbentuk padat dan cair yang digunakan untuk memperbaiki sifat fisik, kimia, dan bilogi tanah. Pupuk organik mengandung banyak bahan organik dari pada kadar haranya. Menurut Sutriana (2016) pemberian pupuk organik cair $10 \mathrm{cc} / 1$ air berpengaruh terhadap berat basah umbi per rumpun dengan rata-rata $306,21 \mathrm{~g}$.

Samadi dan Cahyono (2005), pembentukan umbi bawang merah akan meningkatkan pada kondisi lingkungan yang cocok dimana tunas-tunas lateral akan membentuk cakram baru dan selanjutnya terbentuk umbi lapis. Setiap umbi yang tumbuh dapat menghasilkan 2-14 tunas baru dan akan tumbuh dan berkembang menjadi anakan yang masing-masing akan menghasilkan umbi bawang merah.

Suriyani (2006), menegaskan bahwa semakin tinggi asupan unsur hara maka asimilat yang dihasilkan akan meningkat dan akhirnya cadangan makanan yang tersimpan didalam buah, biji atau umbi pada tanaman akan meningkat sehingga produksi ikut meningkat. Damanik et al (2010) yang menyatakan bahwa kalium sangat dibutuhkan untuk proses pembentukan foto-sintesis serta dapat meningkatkan berat umbi. 


\section{Berat Umbi Kering Per rumpun (gram)}

Hasil pengamatan berat umbi kering per tanaman bawang merah setelah dilakukan analisis ragam memperlihatkan bahwa baik secara interaksi maupun pengaruh utama pemberian pupuk kascing dan poc nasa memberikan pengaruh nyata terhadap berat umbi kering pertanaman.Rerata hasil pengamatan terhadap berat umbi kering setelah dilakukan uji lanjut BNJ pada taraf 5\% dapat dilihat pada tabel 5 .

Tabel 5. Rerata berat umbi kering pertanaman bawang merah dengan perlakuan pupuk kascing dan poc nasa (gram).

\begin{tabular}{llllll}
\hline \multirow{2}{*}{$\begin{array}{c}\text { Pupuk kascing } \\
\text { (g/plot) }\end{array}$} & \multicolumn{4}{c}{ Poc nasa (cc/l air) } & \multirow{2}{*}{ Rerata } \\
\cline { 2 - 5 } & \multicolumn{1}{c}{ P0 (0) } & P1 (2) & P2 (4) & P3 (6) & \\
\hline K0 (0) & $14,47 \mathrm{i}$ & $19,17 \mathrm{fgh}$ & $20,43 \mathrm{efg}$ & $24,43 \mathrm{de}$ & $19,63 \mathrm{~d}$ \\
K1 $(200)$ & $15,85 \mathrm{hi}$ & $23,52 \mathrm{def}$ & $26,94 \mathrm{~cd}$ & $27,13 \mathrm{~cd}$ & $23,36 \mathrm{c}$ \\
K2 (400) & $17,67 \mathrm{ghi}$ & $27,73 \mathrm{~cd}$ & $35,20 \mathrm{ab}$ & $36,37 \mathrm{ab}$ & $29,24 \mathrm{~b}$ \\
K3 (600) & $21,78 \mathrm{efg}$ & $29,08 \mathrm{c}$ & $34,00 \mathrm{~b}$ & $38,60 \mathrm{a}$ & $38,86 \mathrm{a}$ \\
\hline Rerata & $17,44 \mathrm{~d}$ & $24,88 \mathrm{c}$ & $29,14 \mathrm{~b}$ & $31,63 \mathrm{a}$ & \\
\hline KK=5,83\% & BNJK\&P=1,67 & & & BNJ KP $=4,57$ & \\
\hline
\end{tabular}

Angka-angka pada baris dan kolom yang diikuti oleh huruf kecil yang sama tidak berbeda nyata menurut uji lanjut BNJ pada taraf $5 \%$

Data pada Tabel 5, menunjukkan bahwa pengaruh utama pemberian pupuk kascing dan poc nasamemberikan pengaruh nyata terhadap berat umbi kering. Kombinasi perlakuan pupuk kascing $600 \mathrm{~g} /$ plot (K3) yaitu 38,86 g dan berbeda nyata pada perlakuan lainnya, sedangkan perlakuan yang menghasilkan berat kering terendah yaitu tanpa pupuk kascing $(\mathrm{K} 0)$ yaitu $19,63 \mathrm{~g}$.

Tingginya angka pada perlakuan K3P3 hal ini disebabkan pemberian pupuk kascing dan poc nasadapat berinteraksi dengan baik sehingga keduanya mampu menyumbangkan unsur hara makro dan mikro yang dibutuhkan tanaman bawang merah sehingga tanaman mampu melaksanakan proses metabolisme dengan baik, sehingga dapat menghasilkan berat kering lebih tinggi.

Jika dikonversikan per hektar, hasil berat umbi dengan perlakuan K3P3 adalah 9,09 ton/ha, sedangkan hasil produksi bawang merah varietas brebes adalah 9,9 ton/ha (Lampiran 2.). Hal ini karena pemberian pupuk kascing dan poc nasa dilapangan dengan dosis yang diberikan telah mampu mencapai hasil maksimal produksi bawang merah.

Nugrahini (2013) menyatakan bahwa respon tinggi tanaman pada umur 20, 40 dan 60 hari setelah tanam, jumlah daun pada umur 20, 40 dan 60 hari setelah tanam, jumlah anakan pada umur 40 dan 60 hari setelah tanam, berat umbi per petak, dan produksi umbi berbeda sangat nyata terhadap konsentrasi POC Nasa. Produksi umbi paling tinggi dihasilkan pada perlakuan POC Nasa dengan konsentrasi $3 \mathrm{ml} / 1$ air (P4) yaitu $9,12 \mathrm{~kg} / \mathrm{ha}$.

\section{Susut Bobot Umbi (\%)}

Hasil pengamatan susut bobot umbi bawang merah setelah dilakukan analisis ragam memperlihatkan secara interaksi tidak berpengaruh nyata terhadap susut bobot umbi namun pengaruh utama pemberian pupuk kascing dan poc nasa memberikan pengaruh nyata terhadap susut bobot umbi. Rerata susut bobot umbi setelah dilakukan uji BNJ pada taraf 5\% dapat dilihat pada tabel 6 .

Data pada Tabel 6, menunjukkan bahwa interaksi pemberian pupuk kascing dan poc nasa berpengaruh nyata terhadap susut bobot umbi namun nyata secara utama. Kombinasi pemberian pupuk kascing $600 \mathrm{~g} /$ plot dan poc nasa $6 \mathrm{cc} / 1$ air(K3P3) merupakan perlakuan terbaik dengan susut bobot umbi yaitu $30,75 \%$, tidak berbeda nyata terhadap perlakuan K2P3 dengan susut bobot umbi $28,27 \%$, namun berbeda nyata dengan perlakuan lainnya, perlakuan yang menghasilkan susut bobot umbi yang tertinggi adalah tanpa pemberian pupuk kascing dan tanpa pemberian poc nasa (K0P0) yaitu 38,72 \%. Penyusutan umbi dapat dijadikan parameter penentu kualitas yang dilihat dari susut bobot umbi yang dihasilkan. Dimana nilai susut bobot umbi yang semakin rendah menunjukan bahwa kualitas umbi bawang merah tersebut bagus, hal ini juga mempengaruhi masa simpan umbi, yang mana 
semakin rendah susut bobot umbinya maka masa simpan umbi akan lebih lama. Dari penelitian yang telah dilaksanakan susut bobot umbi bawang merah terendah dihasilkan pada pemberian pupuk kascing $400 \mathrm{~g} /$ plot dan Poc nasa cc/l air yaitu $28,27 \%$, hal ini dikarenakan pada dosis tersebut telah dapat memberikan pengaruh yang baik terhadap pertumbuhan bawang merah sehingga pembentukan umbi juga berlangsung baik.

Tabel 6. Rerata susut bobot umbi bawang merah dengan perlakuan pupuk kascing dan poc nasa (\%).

\begin{tabular}{|c|c|c|c|c|c|}
\hline \multirow{2}{*}{$\begin{array}{l}\text { Pupuk kascing } \\
\text { (g/plot) }\end{array}$} & \multicolumn{4}{|c|}{ Poc nasa (cc/l air) } & \multirow{2}{*}{ Rerata } \\
\hline & $\mathrm{P} 0(0)$ & P1 (2) & P2 (4) & P3 (6) & \\
\hline K0 (0) & $50,66 \mathrm{e}$ & $32,19 \mathrm{bcd}$ & $38,93 \mathrm{~d}$ & $33,11 \mathrm{bcd}$ & $38,72 \mathrm{~d}$ \\
\hline K1 (200) & $37,39 \mathrm{~cd}$ & $29,29 \mathrm{abcd}$ & $31,29 \mathrm{bcd}$ & $34,02 \mathrm{bcd}$ & $33,00 \mathrm{c}$ \\
\hline K2 (400) & $27,79 \mathrm{ab}$ & $28,54 \mathrm{ab}$ & $21,88 \mathrm{a}$ & $34,85 \mathrm{bcd}$ & $28,27 \mathrm{~b}$ \\
\hline K3 (600) & $39,44 d$ & $32,51 \mathrm{bcd}$ & 29,18 abc & $21,87 \mathrm{a}$ & $30,75 \mathrm{a}$ \\
\hline Rerata & $38,82 \mathrm{~d}$ & $30,63 \mathrm{c}$ & $30,32 \mathrm{~b}$ & $30,96 \mathrm{a}$ & \\
\hline $\mathrm{KK}=8,55 \%$ & & $\mathrm{BNJK} \& \mathrm{P}=$ & & $\mathrm{BNJKP}=$ & \\
\hline
\end{tabular}

Angka-angka pada baris dan kolom yang diikuti oleh huruf kecil yang sama tidak berbeda nyata menurut uji lanjut $\mathrm{BNJ}$ pada taraf $5 \%$

Data pada Tabel 6, memperlihatkan bahwasannya pengaruh utama pemberian pupuk kascing berpengaruh nyata terhadap susut bobot umbi dengan perlakuan terbaik K2 (400 g/plot) dengan susut bobot $28,27 \%$. Tidak berbeda nyata dengan perlakuan K3.Tetapi berbeda nyata dengan perlakuan lainnya.

Menurut Histifarina (1998) jumlah padatan terlarut berbanding terbalik dengan kadar air dan susut bobot bawang merah. Soedomo (2006) menyatakan, penyusutan umbi bawang merah setelah penyimpanan umumnya 5-30\%. Bawang merah yang memiliki nilai penyusutan terendah, memiliki daya simpan yang baik serta tidak mudah busuk dan berkecambah selama proses penyimpanan.

Bawang merah yang memiliki suatu nilai presentase penyusutan rendah memiliki kandungan air dalam umbi yang ideal sehingga memiliki masa simpan yang lebih panjang. Kekerasan tekstur serta jumlah padatan terlarut pada varietas bawang merah merupakan hal yang mempengaruhi penyusutan umbi saat penyimpanan dan kualitas simpan bawang merah.Bawang merah yang memiliki kekerasan yang baik serta jumlah padatan terlarut yang tinggi akam memiliki kandungan air umbi yang rendah sehingga susut bobot umbi tidak terlalu tinggi.

Data pada Tabel 6 telah memperlihatkan bahwasannya pengaruh utama pemberian Poc nasa berpengaruh nyata terhadap susut bobot umbi dengan perlakuan terbaik yaitu $\mathrm{P} 3(6 \mathrm{cc} / \mathrm{l}$ air) dengan susut $30,96 \%$. Tidak berbeda nyata dengan perlakuan P3.Tetapi berbeda nyata dengan perlakuan lainnya.

Penyusutan umbi dapat dijadikan parameter penentu kualitas dilihat dari susut bobot umbi yang dihasilkan. Nilai susut bobot umbi yang semakin rendah menunjukkan bahwa kualitas umbi tersebut bagus, semakin rendah susut bobot umbinya, maka masa simpan umbi akan lebih lama.

Varietas Super Philip secara genetik memiliki aroma yang kuat, sehingga mampu memberikan susut bobot umbi yang rendah.Sehingga aroma yang kuat akan berhubungan dengan jumlah padatan terlarut.

Suhu siang hari yang tinggi mendukung tanaman untuk berfotosintesis dan menghasilkan fotosintat yang diakumulasi sebagai suatu padatan terlarut dalam umbi. Suhu maksimum pada saat berlangsungnya penelitian ialah $28,27^{\circ} \mathrm{C}$.

Akan tetapi bila terdapat ulat bawangatau hama yang dapat merusak tanaman bawang merah, yaitu seperti serangan hama yang dapat menyebabkan penurunan produksi bawang merah atau penurunan hasil yang tidak sedikit jika tidak dilakukan untuk mencegahpencegahan dan pengendalian. Seperti yang dilakukan penulis, penulis melakukan penyemprotan decis $25 \mathrm{Ec}$,ini termasuk cara secara kuratif, sedangakan secara preventif yaitu dengan cara menjaga kebersihan areal penelitian secara rutin, yang sudah penulis 
jelaskan di bab 3 untuk menangani ulat bawang hama hamayang ada dibawang merah.

\section{KESIMPULAN DAN SARAN}

\section{Kesimpulan}

Dari hasil penelitian yang telah dilaksanakan dapat ditarik kesimpulan bahwa:

1. Interaksi pemberian pupuk kascing dan Poc nasa nyata terhadap, umur panen, jumlah umbi per rumpun, berat umbi kering per tanaman, dan susut bobot umbi. Perlakuan terbaik adalah pupuk kascing $600 \mathrm{~g} / \mathrm{plot}$ dan Poc nasa $6 \mathrm{cc} / \mathrm{l}$ air (K3P3).

2. Pengaruh utama pemberian pupuk kascing nyata terhadap seluruh parameter yang diamati. Perlakuan terbaik adalah pupuk kascing 600g/plot (K3).

Pengaruh utama Poc nasa nyata terhadap seluruh parameter yang diamati. Perlakuan terbaik adalah $6 \mathrm{cc} / \mathrm{l}$ air (P3).

\section{Saran}

Berdasarkan hasil penelitian yang telah dilaksanakan, untuk mendapatkan pertumbuhan dan produksi bawang merah yang baik disarankan untuk melakukan penambahan dosis pupuk kascing yang lebih besar dari $600 \mathrm{~g} / \mathrm{plot}$ dikarenakan produksinya masih kurang dan poc nasa sebanyak $6 \mathrm{cc} / \mathrm{l}$ air. Untuk perawatan harus lebih intensif dalam musim penghujan, karena tanaman akan lebih rentan terserang penyakit.

\section{DAFTAR PUSTAKA}

Anonimous.2015. Produksi Bawang Merah Nasional 2015.www.Pertanian.go.id. Diakses 29 Juli 2018.

Cahyono, B. 2005.Budidaya Jeruk Mandarin. Yogyakarta: Yayasan Pustaka Nusantara.

Damanik, M. M. B., B. E. Hasibuan, Fauzi, Sarifuddin, dan H. Hanum. 2010. Kesuburan Tanah dan Pemupukan. Universitas Sumatera Utara. Medan.

Damari, C. 2012. Toko Online Pupuk Organik Nasa Natural Nusantara Cirebon. http://pupuknasaonline.blogspot.com/201 1/11/poc-nasa.html. (Diakses pada tanggal 15 Juli 2018).

Fahrudin, F., 2009. Budidaya Caisim (Brassica Juncea L.) Menggunakan Ekstrak The dan Pupuk Kascing. Universitas Sebelas Maret, Surakarta.

Histifarina D. dan Musaddad D. 1998. Pengaruh cara Pelayuan daun, Pengeringan dan Daya Simpan Bawang Merah. Jurnal Hortikultura. 8 (1): 10361047.

Mulat, T. 2003 Membuat dan Memanfaatkan Kascing Pupuk Organik Berkualitas. Agromedia Pustaka. Jakarta.

Nugrahini Tutik. (2013). Respon tanaman bawang merah (Allium ascolonicum $\mathrm{L}$. )varietas tuk tuk terhadap pengaturan jarak tanam dankonsentrasi pupuk organik cair nasa. Jurnal Fakultas Pertanian Universitas Widya Gama Mahakam Samarinda. 36 (1) : 60-65.

Pahan .I. 2008.Panduan Lengkap Kelapa Sawit Manajemen Agribisnis dari Hulu Hingga Hilir. Penebar Swadaya. Jakarta.

Samad, S. (2008).Respon Pupuk Kandang Sapi dan KCL terhadap Pertumbuhan dan Produksi Bawang Merah (Alium $\begin{array}{lll}\text { ascalanicum } & \text { L.), } & \text { Buletin }\end{array}$ Penelitian.Lembaga Pene-litian Universitas Hasanuddin.

Sianipar, Joindida Frensisco., Mariati, N Rahmawati. 2015. Karakterisasi dan Evaluasi Morfologi Bawang Merah Lokal Samosir (Allium Ascalonicum L.). Pada Beberapa Aksesi di Kecamatan Bakti Raja. Jurnal Agroteknologi. 1.

Soedomo.2006. Pengaruh Jenis Kemasan dan Daya Simpan Umbi Bibit Bawang Merah Terhadap Pertumbuhan dan Hasil Di Lapangan. Jurnal Hortikultura. Vol 3 : 188-189.

Suriani, N. 2012. Budidaya Bawang Merah dan Bawang Putih. Cahaya Atma Pustaka, Yogyakarta.

Suryana, N.K., 2008. Pengaruh Nau-ngan dan Dosis Pupuk Kotoran Ayam Terhadap Pertumbuhan dan Hasil Paprika (Capsicum annum var. Grossum). J. Agrisains. 9 (2): 89-95.

Sutanto, R. 2005. Dasar-dasar Ilmu Tanah Konsep dan Kenyataan. Kanisius: Yogyakarta.

Sutriana, Selvia. 2016. Pengaruh Pupuk POMI dan NPK Grower terhadap Hasil Bawang Merah (Allium ascalonicum L.). Jurnal Dinamika Pertanian. 32(1) : 27-3 
